\title{
Kuluttajakansalainen syntyy yhteisössä
}

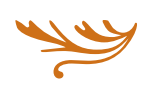

KulutTAMiSella mUUteTAan aina maailmaa: Suomi tarvitsee talouskasvun ja työllisyyden tukemiseen kuluttajakansalaisia, vastuullisia yrityksiä sekä eettisesti toimivia yhteisöjä, mutta samalla kansalaiset ovat aikaisempaa kiinnostuneempia kuluttamisen vähentämisestä ja kohtuullistamisesta.

Onko olemassa oikeaa kuluttamista? Sosiaalisessa mediassa ilmiöistä kasvaa nopeasti aktiivista toimintaa, kuten Tavara päivässä pois -liike osoittaa. Jokaista ostettua tavaraa kohden tulee vähentää vähintään saman verran, tai vastaavasti jokaisena vuoden päivänä tulee luopua yhdestä turhakkeesta.

Kimmokkeen Suomeen tuodulle kulutuksen kohtuullistamiskeskustelulle antoi dokumenttiohjaaja Petri Luukkainen, joka siirsi koko omaisuutensa varastoon. Takaisin sai hänen mallissaan hakea yhden tavaran päivässä. Tapasin Luukkaisen ja hän kertoi, kuinka henkilökohtaisesta vastarintaliikkeestä on kiinnostuttu jopa Suomen rajojen ulkopuolella. Uskon nyt, että taiteen ja dokumenttielokuvien keinot ovat myös kuluttajaliikkeen ohjaamisessa rajattomat.

\section{YHTEISKUNTAVASTUUTA YHÄ ENEMMÄN}

Työskentelin pitkään Kirkon Ulkomaanavussa (KUA), joka on Suomen merkittävimpiä kehitysyhteistyöjärjestöjä. Kuluttajavalistusta ja kansalaiskasvatusta antavana toimijana KUA kiinnitti jo vuonna 2009 nuorten changemaker-verkostolaisten kautta huomiota kännyköissä käytettävien metalliosion kyseenalaiseen alkuperään. Osia tuli esimerkiksi Kongon demokraattisen tasavallan kaivoksista.

Matkapuhelinten ja muiden elektronisten laitteiden valmistamiseen liittyy edelleen monia epäkohtia. Laadimme vetoomuksen, jossa vaadimme silloista Nokiaa olemaan edelläkävijä ongelmien korjaami- sessa. Pyysimme heitä selvittämään käyttämiensä raaka-aineiden alkuperän, julkistamaan alihankintaketjunsa ja tekemään yhteistyötä raaka-ainetuotannon riippumattoman valvontajärjestelmän luomiseksi. Nokia ei lähettänyt koskaan edustajaansa vastaanottamaan vetoomustamme.

Nykyisin yritysten on huolehdittava yhteiskuntavastuullisuudestaan kuluttajakansalaisille, jotka ovat entistä tietoisempia ihmisoikeus- ja ympäristörikkomuksista sekä tuotantoprosessien laiminlyönneistä. Nyt kännyköissä voidaan kierrättää metalleja halvemmalla, ja kyseenalaisissa louhoksissa ei tarvitse enää louhia raaka-aineita. Ilmiö on osa urban mining -ajattelua, urbaania louhintaa, joka hyödyntää raakaaineena käytettyä tavaraa. Kierrätyksen kulttuuri luo innovaatioita, joita kuluttamisen kulttuuri voi tulevaisuudessa hyödyntää täysin uusilla toiminta-aloilla.

\section{MEDIA LUO KULUTUSMIELIKUVAT}

Suomessa on harjoitettu pitkään kasvupolitiikkaa keskittymällä koulutuksen ja innovaatioiden kehittämiseen, ja tuotemarkkinakilpailua on lisätty sääntelyä purkamalla. Jos verrataan suomalaisia muihin pohjoismaisiin kuluttajiin, viime vuosien talouslamassa ruotsalaista kuluttajaa on kannustettu käyttämään rahaa vanhaan malliin. Tämä on vahvistanut kansantalouden myönteistä kehitystä, ja kansalaisten hyvinvointi on pysynyt vakaana. Miksi suomalaiset ovat herkempiä reagoimaan talouden uhkiin?

Kuluttajatutkimuskeskuksen tutkimuspäällikkö Anu Raijas otti kantaa kuluttamiseen 30.11.2013 Helsingin Sanomain vieraskynässä. Valtaosa ruotsalaisista on säilyttänyt uskon omaan taloustilanteeseensa, ja sen vuoksi kansalaisten ostovoima on ollut finanssikriisin jälkeen Suomea parempi. Raijas 
uskoo, että Ruotsissa on vältetty talouden uhkakuvien luoma negatiivinen kierre. Tilastojen mukaan Suomessa kulutus väheni vuonna 2009 lähes neljä prosenttia. Vähensimme kaikkea paitsi välttämättömyyskulutusta eli esimerkiksi asumista ja ruokaa. Kulutuksen kasvu lähti nousuun vuosina 2010 ja 2011, mutta laski jo vuonna 2012.

Median, mainonnan ja kaupallisen teollisuuden rooli kuluttajien valinnoissa ja kuluttajakansalaisen mallin luomisessa on merkittävä ja kasvava. Erityisesti sosiaalinen ja sähköinen media luovat mielikuvaa ihmisestä, jonka pääasiallinen tehtävä on kuluttaminen osana omaa hyvinvointia ja elämänhallintaa.

Nuorille tärkein kuluttamisen viitekehys median rinnalla ovat kaverit ja vertaisryhmät, joiden kesken arvioidaan omaa kulutuskäyttäytymistä ja minuutta. Kuluttajat eivät enää usko brändien kertomuksiin itsestään. Kuluttajan raamattu on toinen kuluttaja. Sosiaalisen median vaikutusvalta perustuu suosituksiin ja toisten kertomaan: siihen, mitä joku toinen pitää hyvänä. Siksi kohtuullisuuteen pyrkivät ekokampanjat ja -paastot, vastakuluttamisliikkeet ja kansalaisista lähtevä liikehdintä ovat aina ilahduttavia ja kestävää muutosta aikaansaavia toiminnan muotoja. Mikään ei kuitenkaan voi korvata perheen ja koulun merkitystä kuluttajakasvatuksessa.

Olen seurannut yli 16 vuotta nykyisten teinieni elämää ja saanut ilahduttavasti kokea, että nuoret ovat monesti fiksumpia ja valistuneempia sekä ehdottomampia kulutuskäyttäytymisessään kuin me edeltävät sukupolvet. Kun poika tulee koulusta ja ripittää vanhempia veden-, sähkön tai auton kulutuksesta, on vastuullisuudella tulevaisuuden toivon kasvot.

\section{Vaihtoehto kulutusidentiteetille}

Kulutusta ja kasvua ei pidä pysäyttää, mutta kaikki kuluttaminen ei ole yhtä arvokasta tai tärkeää työllisyyden lisäämisenkään näkökulmasta. Materialismin kasvu ei ole lisännyt ihmisten hyvän elämän kokemusta ja onnellisuutta. Tarvitsemme tavarataivaiden tilalle merkitystä hyvän tekemisestä, toisten välittämisestä, oman itsen huomioimisesta ja lähimmäisten palvelemisesta. Haluamme kuluttaa aineettomia palveluja, joiden suosio lisääntyy.
Hyvän elämän kokemus ei synny kuluttamisella, vaan merkityksen löytymisellä, hyvän tekemisellä, yhteisöön kuulumisella ja toisten huomioimisella. Kuluttaja voi valinnoillaan tehdä kestävän kehityksen mukaisia päätöksiä, joiden seurauksena ympäristön-, elämän- ja yhteiskunnan toiminnot ovat vastuullisempia.

Kolmannen sektorin järjestönä esimerkiksi Marttaliitto on antanut kestävän kehityksen strategiatyöryhmälle yhteiskuntasitoumuksen: "Marttaliitto sitoutuu edistämään kansalaisten asenteita kestäviä valintoja kohtaan sekä lisäämään tietoja, joiden avulla ekologinen jalanjälki pienenee. Kursseilla, luentotilaisuuksissa ja työpajoissa osallistujia opastetaan kestäviin valintoihin. Uutena neuvontamenetelmänä käytetään verkko-opintoja.”

Kulutus muovaa elämäntapaamme, asenteitamme ja suhdettamme itseemme, toisiimme sekä ympäristöömme. Siksi kuluttaminen ja sen kohtuullistaminen ovat osa identiteettiämme ja elämäntapojamme. Jos haluamme jättää tuleville sukupolville kestävää perintöä, meidän tulisi tehdä valintoja kierrätettävän kuluttamisen puolesta. Kuluttamiseen perustuvalle identiteetille on aina olemassa vaihtoehtoja, joita esimerkiksi kristillinen kulttuuri ja teologia ovat vuosituhansien ajan ylläpitäneet paastoperinteen ja kohtuullisuuden välityksellä.

Haluan ajatella kuluttamisesta hyvää. Yhteisinä päämäärinämme täytyy olla globaali vastuu, ylisukupolvinen ratkaisujen löytyminen sekä toimintamme sopeuttaminen luonnon kantokyvyn rajoihin. Tarvitsemme vanhempina ja kasvattajina osaamista, tietoa, taitoa ja luovuutta kestävien ratkaisujen löytymiseksi. Tärkeää on yhdessä tekeminen ja mallintaminen. Näin toiminnoista tulee tapoja ja tottumuksia, ja syntyy elämänkaaren läpi kantavaa hyvinvointia. Kasvatuksen ja kohtuullisen kuluttamisen kautta luodaan perustaa kestävälle yhteiskunnalle.

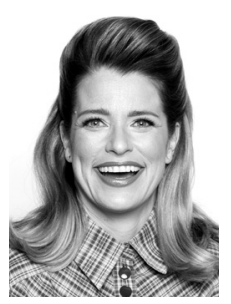

Marianne Heikkilä

Marttaliitto

Toiminnanjohtaja, pappi,

kahden teinin helsinkiläinen äiti 